\title{
Month of the Year Effect in Indonesia Stock Exchange
}

\author{
Agus Arman ${ }^{1}$ and Zakaria ${ }^{2}$ \\ ${ }^{1}$ Lecturer, Management Studies Program, Sekolah Tinggi Ilmu Manajemen Nitro, Makassar, \\ Indonesia \\ ${ }^{2}$ Lecturer, Management Studies Program, University of YAPIS, Papua, Indonesia
}

Corresponding Author:

Agus Arman

agus.arman@nitromks.ac.id

Received: 30 December 2019

Accepted: 29 January 2020

Published: 6 February 2020

Publishing services provided by

Knowledge E

(c) Agus Arman and Zakaria. This article is distributed under the

terms of the Creative Commons

Attribution License, which

permits unrestricted use and

redistribution provided that the

original author and source are credited.

Selection and Peer-review under the responsibility of the 6 th ICOEN 2019 Conference Committee.

\section{G OPEN ACCESS}

\begin{abstract}
This study examines the phenomenon of the month of the year effect on sectoral stock indices on the Indonesia Stock Exchange (IDX). The data used is monthly closing price data for sectoral stock price index during the period of 2016 to 2018 obtained from IDX (idx.co.id). Data analysis was performed using the one sample $t$ test model. To test the hypothesis, ANOVA is used, using SPSS version 23. The results of this study show that: the agriculture index experienced a significant increase in every April, the mining index experienced a significant increase in every July, the basic industry index experienced a significant increase in April, miscellaneous industry indices experienced a significant decline in every May, the consumer goods index experienced a significant decline in every May, the property and real estate index did not experience a significant increase or decrease based on the month, infrastructure index experienced a significant increase in each of June and December, the finance index experienced a significant increase in every July and September, and the trade and service index did not experience a significant increase or decrease based on the month.
\end{abstract}

Keywords: month of the year effect; stock return; stock sectoral index; IDX

\section{Introduction}

One important breakthrough in the development of corporate financial theory, is the importance of efficient market hypotheses initiated by Fama in 1970. Since it was discovered, this theory seems to be a magnet for many financial researchers to continue to be tested for its truth. Many financial management experts such as Miller (1999) explicitly say that one of the important findings in the history of the development of financial management theory is efficient market theory. Of the many financial theories, efficient market theory is the one that gets the most attention and empirically tested in almost all world capital markets.

In theory, a market is said to be efficient if no one, both individual investors and institutional investors, will be able to obtain abnormal returns, using existing trading 
strategies. That is, the prices formed in the market reflect various information available. Another view states that in an efficient market, the prices of an asset or security reflect the available information about the asset or security.

But the peculiarities caused by the effects of calendar in the capital market, for example in the form of anomalies, are closely related to the efficient capital market hypothesis. Anomalies will cause market efficiency to experience interference. This anomaly will result in errors in pricing securities. This situation occurs as a result of errors and assumptions used by the market. Thus, market anomalies cannot be completely lost, because the factors that influence them are still added to by investor behavior factors in addressing information on the market.

Calendar anomalies are one of several market anomalies that disrupt the efficient market hypothesis. Based on studies on calendar anomalies conducted in several capital markets in the world, proving the existence of seasonality returns, day of the year effects, and month of year effect. This shows that this peculiarity occurs repeatedly so that it can be said as an interesting phenomenon to be observed and examined in the capital market.

The phenomenon of the month of the year effect is a phenomenon that attracts the attention of many researchers. Research on the month of the year effect conducted by Boudreaux (1995), found there was a month of the year effect on the stock market in the Pacific region. The same was found in the studies of Bahadur and Joshi (2005) on the stock market on the Nepal Stock Exchange, Thushara and Perera (2013) on the Colombo Stock Exchange, and Alagidede (2013) on the African Stock Exchange. While in Indonesia, Robiyanto (2015) found the phenomenon of the month of the year effect on almost all stock markets in the ASEAN region. In this study, testing the month of year effect will be carried out on 9 sectoral stock indices on the Indonesia Stock Exchange during the period 2016-2018 which include: agriculture, mining, basic industry, miscellaneous industry, consumer goods, property and real estate, infrastructure, finance, and trade and services. The aim is to find a monthly (seasonal) pattern on sectoral stock indices.

\section{Literature Review}

\subsection{Efficient Market Hypothesis}

The basic concept of efficient markets was first put forward and popularized by Fama (1970). A market is said to be efficient if the security price fully reflects all relevant 
information available, both historically, publicly, and privately. So an efficient market is shown by the price of a security whose value is equal to its fundamental value.

Studying the concept of efficient markets, attention will be directed to the extent and how quickly the information can affect the market which is reflected in changes in securities prices. In this case Haugen (2001) divided information groups into three, namely (1) information on past stock prices (information in past stock prices), (2) all available information including public information (all public information), and (3) all available information including inside information (all available information including inside or private information). Each group of information reflects the extent of the efficiency of a market.

\subsection{Market Anomaly}

Discussing efficient market testing, it must also discuss the existence of an anomaly that is related to the efficient market hypothesis. In anomalies found things that should not exist if it is considered that an efficient market really exists. Existing anomalies are not only found in one type of efficient market form, but also found in other forms of efficient markets. That is, empirical evidence of anomalies in the capital market arises in all forms of efficient half-strong.

In financial theory, there are at least four kinds of market anomalies. These four anomalies are company anomalies, seasonal anomalies, event anomalies or events, and accounting anomalies. Various forms of anomalies that occur in the capital market, explained by Schwert and Smith (2003) in Constantinides, et al (2003). These anomalies include: size effect, turn of the year effect, the weekend effect, the value effect, and the momentum effect. It was also explained that these anomalies tend to disappear or weaken.

Anomalies about efficient markets can also be explained from the point of view of financial behavior, as was done by Shefrin (2008) who divided the anomalies into three groups, namely: First, the long-term reversal: winner-loser effect. De Bondt-Thaler (2003) research results, historically the worst performing stocks for a period of 1 year, have a tendency to out perform on the market in the next 5 years by 30 percent. Conversely, stocks with the best return in the past 3 years tend to under perform against the market in the next 5 years by 10 percent. This situation is called the winner-loser effect.

Second, Momentum: short-term continuation, where in the short term, return indicates momentum (not a reservoir). Historically, portfolios formed by holding winners and selling 
loser shares obtained from a period of 6 months ago will yield more than 10 percent per year. This pattern mainly occurs in small capitalized stocks. So in the short term, losers stocks tend to underperform in the next period and winners stocks tend to out perform against the market in the next period. Third, Post-earnings announcement drift, where the company's stocks that gave a positive surprise earning increase will show positive performance after the earnings announcement, while stocks that gave a surprise earnings increase negative will show a negative performance after the earnings announcement.

\subsection{Seasonal Influence on Stock Returns}

This theory is explained by Gultekin and Gultekin (1983) and Raj and Kumari (2006) to explain the seasonal influence of daily returns. Seasonal influences on daily returns are explained through four stages, namely: Settlement period hypothesis, namely the price tends to increase on the payment day (date) of settlement announcement. The calender time/trading time hypothesis, that is, Monday's return is an accumulation of the return of Saturday and Sunday holidays.

The cause of the Monday effect is because; (1) Information flow hypothesis, that is, companies tend to hold negative information until the weekend and give investors time to absorb the negative information for 2 days. Later on Monday, new investors reacted to the information received last Sunday, the result is Monday's return will be negative. (2) Retail investor trading hypothesis, namely the occurrence of a high trading activity for the small size trade on Monday, while for large size trade, the activity is low.

While the Month of the year effect, Raj and Kumari (2006) construct 2 (two) hypotheses, namely: Tax-loss selling hypothesis, namely the existence of a negative return in December relating to the preparation of financial statements, and the return will be positive in January, and portfolio rebalancing, namely in January, institutional investors improved their portfolios. This is known as the behavioral finance irrational exuberance phenomenon.

\subsection{Month of the year Effect}

Month of the Year Effect occurs when there is a return on a month that is higher or lower than the other month. A common pattern in the Month of the Year Effect is the January Effect where stock returns in January are usually higher than in previous months. 
This happened because investors rearranged their portfolios and bought shares at the beginning of the year (Arman, 2018).

Several studies related to the Month of the Year Effect have been carried out by Mouselli and Al-Saman (2016) on the Damascus Stock Exchange and Patel (2016) who conducted studies on the capital markets of the United States, Latin America and the emerging capital market categories. Both of these studies generally found that there were effects of trading months on stock returns. Mouselli and Al-Saman (2016) even concluded that may tends to produce positive returns, while Patel (2016) found that the January Effect is unlikely to occur, but other trading months have an impact on stock returns. In the ASEAN region, research on the Month of the Year Effect has been carried out by Robiyanto (2015), finding the existence of the Month of the Year Effect on capital markets in ASEAN and in the commodity market. Arman (2018) found that the share price of banking companies experienced a significant difference in every April and June.

\subsection{Method}

The data used in this study are secondary data, in the form of monthly sectoral stock index data issued by PT. Indonesia stock exchange. The research period is 2016-2018. To test the existence of month of the year effect, one sample t-test model is used as below. To test the hypothesis, ANOVA is used, with the use of data using the SPSS version 23.

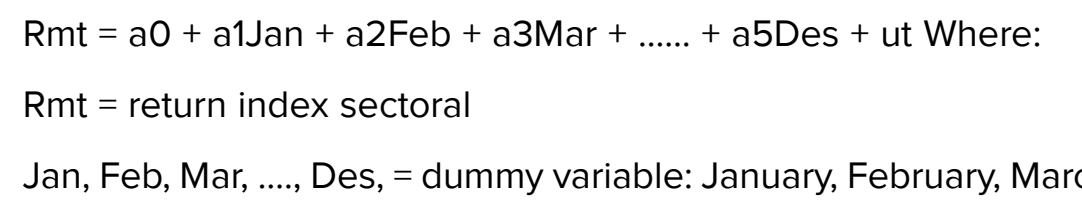
., and December

\section{Results}

\subsection{Testing Month of the Year Effect}

One-sample testing whether you want to test whether or not a given value is given. The results of calculations with the help of SPSS version 23, the full researcher added to the attachment sheet (appendix) of this text. The results of the study based on the appendix show complete results about the difference in sectoral index returns based on the month. 
In accordance with the purpose of this study, which is to provide evidence of a particular month, the sectoral stock index experienced a significant increase or decrease. Due to the limitations of page space, the results of our study are concise in 1.1.

Based on table 1.1, it shows that the agricultural sector stocks experienced a significant decline every April, the mining sector shares experienced a significant increase every July, the basic industrial sector shares experienced a significant increase every April, Shares the share of the various industrial sectors experienced a significant decline every May.

The results also showed that the consumption sector shares experienced a significant increase in each month, property sector stocks did not experience a significant increase or decrease based on the month, infrastructure sector stocks experienced a significant increase every June and September, Financial sector stocks experienced a significant increase in July and September, and trading sector stocks did not experience a significant increase or decrease based on the month.

\section{Discussion}

The findings as shown in table 1.1 can be explained as follows:

Agriculture Sector. The agriculture sector in the Indonesia Stock Exchange (IDX), consisting of plantation, livestock, fisheries and other agricultural sub-sectors. Various research conducted on determinants of stock performance in the agricultural sector, such as those carried out by Andiantyo, et al (2018), Apriyani, et al (2016), and Artha, et al, palm oil in the form of CPO. This is inseparable from several issuers with the largest capitalization value at IDX, a company engaged in oil palm plantations. Therefore, the decline in the agricultural stock index significantly in April, allegedly due to a decline in CPO prices for the month. This is in line with the results of Sebayang (2018).

Mining Sector. The mining sector at IDX consists of coal, oil and gas, other metals and minerals, rocks and other mines. Various research results show that the main factor determining the performance of shares in the mining sector is the development of coal, copper, gold, tin, nickel and rupiah exchange rates (Amaliya, 2017; Setianto, 2016; and Agustina, 2014). In addition, because the commodity is an export destination, winter factors and rainfall factors in Indonesia are also influential (Sebayang, 2018). Therefore, the rise in mining stock prices significantly in July, allegedly because of increased demand for stocks facing the winter in Europe and July in Indonesia coincides with low rainfall. 
TABLE 1: Month of the Year Effect Based on the performance of sectoral stock indices.

\begin{tabular}{|c|c|c|c|c|c|c|}
\hline \multicolumn{7}{|c|}{ One-Sample Test } \\
\hline & \multicolumn{6}{|c|}{ Test Value $=0$} \\
\hline & \multirow[t]{2}{*}{$\mathrm{t}$} & \multirow[t]{2}{*}{ df } & \multirow[t]{2}{*}{$\begin{array}{l}\text { Sig. (2- } \\
\text { tailed) }\end{array}$} & \multirow[t]{2}{*}{$\begin{array}{c}\text { Mean } \\
\text { Difference }\end{array}$} & \multicolumn{2}{|c|}{$\begin{array}{l}\text { 95\% Confidence Interva } \\
\text { of the Difference }\end{array}$} \\
\hline & & & & & Lower & Upper \\
\hline \multicolumn{7}{|c|}{ Agriculture } \\
\hline Apr & -4.056 & 2 & $\left..056^{*}\right)$ & -.0449602 & -.092651 & .002731 \\
\hline Mei & -1.980 & 2 & .186 & -.0337405 & -.107047 & .039566 \\
\hline \multicolumn{7}{|c|}{ Mining } \\
\hline Jul & 4.772 & 2 & $\left..041^{* *}\right)$ & .0923189 & .009084 & .175554 \\
\hline Agt & -.942 & 2 & .445 & -.0207538 & -.115509 & .074002 \\
\hline \multicolumn{7}{|c|}{ Basic_Industry } \\
\hline Apr & 4.995 & 2 & $\left..038^{* *}\right)$ & .0386767 & .005359 & .071995 \\
\hline Mei & -.188 & 2 & .869 & -.0062802 & -.150340 & .137779 \\
\hline \multicolumn{7}{|c|}{ Misc Industri } \\
\hline Mei & -9.364 & 2 & $\left..011^{* *}\right)$ & -.0206365 & -.030119 & -.011154 \\
\hline Jun & .671 & 2 & .571 & .0250833 & -.135830 & .185996 \\
\hline \multicolumn{7}{|c|}{ Consumer } \\
\hline Mei & -3.660 & 2 & $\left..067^{*}\right)$ & -.0099160 & -.021572 & .001741 \\
\hline Jun & .413 & 2 & .720 & .0052771 & -.049714 & .060268 \\
\hline \multicolumn{7}{|c|}{ Property } \\
\hline Jul & 2.156 & 2 & .164 & .0187543 & -.018672 & .056180 \\
\hline Agt & 1.508 & 2 & .271 & .0143395 & -.026567 & .055245 \\
\hline \multicolumn{7}{|c|}{ Infrastructure } \\
\hline Jun & 16.435 & 2 & $\left..004^{* *}\right)$ & .0315943 & .023323 & .039866 \\
\hline Des & 3.808 & 2 & $\left..063^{*}\right)$ & .0307864 & .003996 & .065569 \\
\hline \multicolumn{7}{|c|}{ Finance } \\
\hline Jul & 4.316 & 2 & $\left..050^{* *}\right)$ & .0477090 & .000152 & .095266 \\
\hline Spt & 3.675 & 2 & $\left..067^{*}\right)$ & .0192627 & -.003290 & .041816 \\
\hline \multicolumn{7}{|c|}{ Trade } \\
\hline Nop & -1.455 & 2 & .283 & -.0229419 & -.090806 & .044922 \\
\hline Des & 1.523 & 2 & .267 & .0214677 & -.039163 & .082098 \\
\hline
\end{tabular}

Source: output SPSS, processed

Basic Industrial Sector. The Basic and Chemical Industry Sector at IDX consists of the cement, ceramic, porcelain and glass, metal and the like sub-sectors, chemicals, plastics 
and packaging, animal feed, wood and its processing, pulp and paper, and other basic industries. For this sector, the performance of the index is mainly influenced by the performance of issuers from the cement and animal feed sub-sector (Prasetiono, 2018 and Damayanti, 2014), where several issuers from the sub-sector are members of the LQ45 index. Therefore, rising share prices in the basic industrial sector are allegedly due to improving stock performance of the cement sub- sector issuers and animal feed sub-sector.

Miscellaneous Industry Sectors. The Miscellaneous Industry in IDX consist of submachines and heavy equipment, automotive and its components, textiles and garments, our bases, cables, electronics, and various other industries. In this sector, the automotive sub sector issuers and their components, especially PT. Astra International (ASII) has the greatest weight and most affects various industry indices (Hartanto, 2019). The significant decline in the share price of this sector in May was allegedly due to the fact that every April and May, the largest automotive exhibition in Indonesia was held which also involved rivals ASII, especially automotive from China, Europe and America.

Consumer Good Sector. The Consumer Good Sector at IDX consists of food and beverage, cigarette, pharmaceutical, cosmetics and household goods sub-sectors, other consumer goods. The shares of this sector are often the backbone of the $\mathrm{JCl}$, especially because in this sector there are several companies with large capitalization values such as issuers of UNVR, INDF, MYOR, HMSP, GGRM, KLBF, and ICBP. The significant decline in share prices in this sector in May was allegedly due to the factors of the month of Ramadan which occurred around April and May.

Property and Real Estate sector. Property and Real Estate sector in IDX, consisting of property and real estate sub-sectors, building construction, and other properties. The results of the study showed that there were no months in which the share price of this sector experienced a significant increase or decrease. This was allegedly because investors were still taking a wait and see position in this sector (Jordan, 2018).

Infrastructure Sector. The Infrastructure Sector in IDX consists of the energy subsector, toll roads, ports, airports and the like, telecommunications, transportation, nonbuilding construction, and other infrastructure. The high development of infrastructure in Indonesia has also triggered an increase in the share price of this sector. Based on the results of the study, the share price of the infrastructure sector experienced a significant increase in June and December. This is allegedly caused by the process of exposing the government's infrastructure budget which usually occurs in June and at the end of the fiscal year (Sebayang, 2018). 
Financial Sector. The Financial Sector at IDX consists of bank sub-sectors, financial institutions, securities companies, insurance, mutual funds, and other finance. Various research results indicate that the banking sub-sector has a large contribution to the performance of the financial index. This is not surprising because currently there are 43 banking issuers listed in the banking sub-sector, some of which have assets above Rp.200 trillion which are permanent members of the LQ45 index. Therefore, it is suspected that there is a strong correlation between the performance of the shares of the banking sub-sector and the rising stock prices of this sector in July and September.

Trade Sector. The Trading Sector at IDX consists of large trade sub-sectors, retail trade, restaurants, hotels, and tourism, advertising, printing, and media, health, computer services and devices, investment companies, and other trade. The results of the study showed that there were no months in which the share price of this sector experienced a significant increase or decrease. This is allegedly because in this sector it is a collection of issuers whose business is related to daily needs.

\section{Conclusion and Suggestions}

The results of the research on the phenomenon of the month of the year effect on the sectoral stock price index on the Indonesia Stock Exchange provide a conclusion: Agriculture index experienced a significant increase every April, the mining index experienced a significant increase in July, basic industry index experienced a significant increase in April, miscellaneous industry index experienced a significant decline in each month, the consumer goods index experienced a significant decline in every May, property and real estate index did not experience a significant increase or decrease based on the month, Infrastructure index experienced a significant increase in every June and December, finance index experienced a significant increase in every July and September, and trading and service index did not experience a significant increase or decrease based on the month.

For further research, it is recommended to use a longer research period (in research using only 3 years of data) and further research can deepen the cause of the phenomenon of the month of year effect on sectoral stock indices, because in this study, the answer to the month of the year effect is still limited as a temporary guess. 


\section{References}

[1] Agustina dan Fitry Sumartio. 2014. Analisis Faktor-Faktor Yang Mempengaruhi Pergerakan Harga Saham Sektor Pertambangan. Jurnal Wira Ekonomi Mikroskil. Volume 4, Nomor 01, April 2014.

[2] Alagidede, Paul. (2013). Month of the Year and Pre-Holiday Effects in African Stock Markets. Seminar Nasional AVoER IX 2017 Palembang, Universitas Sriwijaya Palembang.

[3] Amaliya Ninda Nur. 2017. Analisis Statistik Faktor-Faktor Yang Mempengaruhi Pergerakan Harga Saham Sektor Pertambangan. Tesis. Departemen Statistika ITS Surabaya. 2017.

[4] Andiantyo Prakosa, Pardomuan Sihombing, Sri Yani Kusumastuti. 2018. Pergerakan Harga Saham Sektor Pertanian di Bursa Efek Indonesia. Seminar Nasional Cendekiawan ke 4 Tahun 2018. ISSN (P): 2460 -- 8696.

[5] Apriyani, Nurrahmah, Wiwiek Rindayati, dan Ranti Wiliasih, 2016, Analisis Pengaruh Variabel EPS dan Makroekonomi terhadap Return Saham Jakarta Islamic Index Sektor Pertanian, Jurnal al-muzara'ah, vol. 3, no. 1, 44-61.

[6] Arman Agus and Lestari Dwi Ayu. 2018. Testing the Monday Effect in the Banking Sector In Indonesia Stock Exchange. Proceeding: International Conference on Accounting, Management, and Economics (ICAME), 4th--5th November 2018, Hasanuddin University, Indonesia.

[7] Artha, Danika Reka, Noer Azam Achsani, dan Hendro Sasongko, 2014, Analisis Fundamental, Teknikal dan Makroekonomi Harga Saham Sektor Pertanian. Jurnal manajemen dan kewirausahaan, Vol. 16, no. 2, 175-184.

[8] Bahadur, F. K. C., dan N. K. Joshi. 2005. The Nepalese Stock Market: Efficient and calendar anomalies. Economic Review: Occasional Paper of Nepal Rastra Bank 17: 40-85.

[9] Boudreaux, D. O. 1995. The monthly effect in international stock markets: Evidence and implications. Journal of Financial and Strategic Decisions 8(1): 15-20.

[10] Constantinides GM, Hariis M, and Stulz R. (2003). Anomalies and Market Efficiency. Handbook of the Economics of Finance. Elseiver Science BV.

[11] Damayanti, Verra. Analisis Hubungan Variabel Makro Ekonomi terhadap Indeks Harga Saham Sektoral di Bursa Efek Jakarta. Tesis. Universitas Indonesia.

[12] De Bondt and Thaler. (2003). Futher evidence of investor overreaction and stock market seasonality. Journal of Finance. 42 (3) pp 557-582. 
[13] Fama Eugene. (1970). Efficient capital market; A review of theory and empirical work. Jurnal of Finance, 25, pp.383-417.

[14] Gultekin MN and Gultekin NB. (1983). Stock market seasonality: international evidance. Journal of finance economics, 12, pp.469-481.

[15] Hartanto. 2018. Capital Market out Look 2019. Head of Research Reliance Securities. Work Paper.

[16] Jordan Dennies Christoper. 2018. Capital Market out Look 2019. Head of Research Artha Sekuritas Indonesia. Work Paper.

[17] Miller, Merton. (1999). The History of Finance. Journal of Portfolio Management, 25 (4): 95- 101.

[18] Mouselli, S., dan H. Al-Saman. 2016. An examination of the month-of-the-year effect at Damascus securities exchange. International Journal of Economics and Financial Issues 6(2): 573-577

[19] Patel, J. B. 2016. "The January effect anomaly reexamined in stocks returns". Journal of Applied Business Research 32 (1).

[20] Prasetiono Surya Pamungkas. 2018. Analisis Pengaruh Harga Minyak Dunia, Kurs Rupiah/US Dollar, Fed Rate Terhadap Indeks Sektoral Pasar Saham di Indonesia. Diponegoro Journal of Management, Volume 7, Nomor 2, Tahun 2018, Halaman 1-14.

[21] Raj Mahendra and Kumari Damini. (2006). Day of the week and other market anomalies in the Indian Stock Market. International Journal of Emerging Markets. Vol.1, No.3, pp.235- 246.

[22] Robiyanto, 2015. Month of the year effect pada beberapa pasar modal di Asia Tenggara dan pasar komoditas. Jurnal Ekonomi dan Bisnis 18(2): 53-64.

[23] Schwert, G.W. dan Smith W. Clifford Jr. (2012). Empirical Research in Capital Market, McGraw-Hill, Inc, USA.

[24] Sebayang Edwin. 2018. Capital Market out Look 2019. Head of Research MNC Securities. Work Paper.

[25] Setianto, B. 2016. Analisa Seluruh Industri Sektor dan Semua Sub Sektor Saham di BEI 2015. Jakarta: Stock Valuation Calculator (BSK Capital).

[26] Shefrin, H., (2008). Risk and Return in Behavioral SDF-Based Asset Pricing Models, Journal of Investment Management, 6, pp. 4-22.

[27] Thushara, S.C. Perera, P. 2013. The month of the year effect: empirical evidence from Colombo stock exchange. Proceedings of the 2nd International Conference on Management and Economics 2013. 